\title{
The Role of Probiotic Bacteria in Protecting against Aflatoxin M1 Contamination in Milk and Certain Dairy Products
}

Rabie, M. A. *; E. M. Abd El-Wahed ${ }^{1}$; M. G. Moustafa ${ }^{2}$; Kh. El-Zahar ${ }^{1,3}$ and A. M. Abdel-Zaher ${ }^{4}$

${ }^{1}$ Department of Food Science, Faculty of Agriculture, Zagazig University, Zagazig, E- 44519 Egypt

${ }^{2}$ Department of Microbiology, Faculty of Agriculture, Zagazig University, 44517 Zagazig, Egypt

${ }^{3}$ Department of Food Science and Human Nutrition, Qassim University, Buraydah, Qassim, Saudi Arabia

${ }^{4}$ Chemistry department, Faculty of Science, Zagazig University, 44551 Zagazig, Egypt

*Corresponding author: Mohamed A. Rabie, PhD

E-mail address: Marabie@agri.zu.edu.eg; Phone number: +2-055-2379224;

Fax number: +2-055-2287567

\begin{abstract}
Purpose:The present study investigated $\mathrm{AFM}_{1}$ contamination in raw milk, kareish cheese and yoghurt and studied the abilities of heating and probiotic bacteria to reduce $\mathrm{AFM}_{1}$ contamination in both raw milk and yoghurt. Methods: $\mathrm{AFM}_{1}$ was detected in raw milk in 10 of 12 samples (83.3\%) from each season. Two methods were used to assess the toxigenic potential. HPTLC was performed for aflatoxin detection. Aflatoxin $\mathrm{M}_{1}$ contamination milk and selected dairy products was investigated against heating and Lactobacillus acidophilus $\mathrm{La}_{5}$ and Bifidobacterium lactis $\mathrm{Bb}_{12}$ and its combination. Result: Cheese had the highest mean values concentration of $\mathrm{AFM}_{1}$ (527.4 and $651.3 \mathrm{ng} / \mathrm{kg}$ ), and yoghurt had the lowest concentration (39.13 and $64.68 \mathrm{ng} / \mathrm{kg}$ ) while, raw milk samples were (207.0 and $311.8 \mathrm{ng} / \mathrm{kg}$ ) during summer and winter, respectively. The concentration of toxin in $83.33 \%$ of the examined cheese samples exceeded the EU limit $(50 \mathrm{ng} / \mathrm{kg}$ ), and $70.83 \%$ of these samples exceeded the Codex limit $(500 \mathrm{ng} / \mathrm{kg})$ during both seasons. Boiling degraded $26.71 \%$ of the $\mathrm{AFM}_{1}$. Whereas, pasteurization only degraded $15.45 \%$. In yoghurt, two strains of probiotic bacteria (Lactobacillus acidophilus and Bifidobacterium lactis) each gradually reduced the $\mathrm{AFM}_{1}$ concentration as a function of time in milk contaminated with $25 \mathrm{ng} / \mathrm{l}$, with complete elimination by the end of the refrigerated storage period ( 3 days), while, the combination of both probiotic bacteria (L. acidophilus and B. lactis) was better able to reduce $\mathrm{AFM}_{1}$ in milk contaminated with $50.0 \mathrm{ng} / \mathrm{kg}$ or $75 \mathrm{ng} / \mathrm{kg}$ $\mathrm{AFM}_{1}$.Conclusion: The most extensive reductions of the $\mathrm{AFM}_{1}$ concentration were to $41.80 \mathrm{ng} / \mathrm{kg}(45.3 \%), 22.6 \mathrm{ng} / \mathrm{kg}(69.90 \%)$ and $7.12 \mathrm{ng} / \mathrm{kg}(92.8 \%)$, which were achieved using the same concentration of each strain individually and in combination, respectively, after two days in milk contaminated with $75 \mathrm{ng} / \mathrm{kg}$. No $\mathrm{AFM}_{1}$ was detected after three days using the combined strains.

Keywords: Aflatoxin $\mathrm{M}_{1}$, raw milk, milk products, heating, probiotic bacteria.
\end{abstract}

\section{INTRODUCTION}

Aflatoxins are a group of secondary toxic and carcino genic metabolites produced by different species of Aspergillu s such as Aspergillus flavus, Aspergillus parasiticus, and Aspergillus nomius (Ito et al. 2001). The growth of Aspergillus toxic species on dairy product may result in one or more aflatoxins contaminating that product. If made from contaminated milk, cheese can possibly contain aflatoxin $\mathrm{M}_{1}\left(\mathrm{AFM}_{1}\right)$, as well as $\mathrm{B}_{1}$ and other aflatoxins if the cheese subsequently supports the growth of toxigenic Aspergilli (van Egmond and Dragacci 2001). Regulation (EC) 1881/2006 and subsequent amendments set maximum levels for mycotoxins and certain other contaminants in food.

Regulation (EC) 401/2006 introduced provisions of sampling and analysis methods for the official control of mycotoxins RASFF Regulation Commission regulation (EU) No 16/2011, FDA (2011); USDA (2016).

$\mathrm{AFM}_{1}$ is the hydroxylated metabolite of aflatoxin $\mathrm{B}_{1}$ produced by the action of the cytochrome $\mathrm{P} 450$ oxidase system present in the ruminal microflora and cells of animals and can be found in milk and later on in other dairy products when lactating animals are fed with contaminated feedstuffs (van Egmond et al. 2007; Motawee et al. 2009); (Dashti et al. 2009). (Bakirci 2001) detected varying increases in the $\mathrm{AFM}_{1}$ content of yoghurt in relation to contaminated milk. Fermentation effect was assessed by (Govaris et al. 2002) who found that levels of $\mathrm{AFM}_{1}$ were significantly lower for all yogurt samples than those initially present in milk. Factor such as low $\mathrm{pH}$, the formation of organic acids and other by-products of fermentation, and the presence of lactic acid bacteria (LAB) were attributed to this reduction of $\mathrm{AFM}_{1}$. Contamination levels of $\mathrm{AFM}_{1}$ were significantly higher in autumn and winter samples than in spring and summer samples (Kamkar, 2005).

The European Union (No 2006) established lower maximum allowable levels for $\mathrm{AFM}_{1}$ at $50 \mathrm{ng} / \mathrm{kg}$ for milk and $250 \mathrm{ng} / \mathrm{kg}$ for cheese. The European Union standards have been followed in many other countries (Dashti et al. 2009). In Egypt, the ministry of health established in 1990 that fluid milk and dairy products should be free of $\mathrm{AFM}_{1}$, and the current maximum permissible levels follow the European Union standard (Egyptian Standard 1990). AFM in milk products represents a serious risk to health hazard of consumers, especially kids, who are more sensitive than adults to aflatoxin's adverse effects (Fallah 2010).

A total of 50 raw milk samples and 150 from samples were analysed (each of 50 from soft cheese, hard cheese, and processed) and the mean concentrations of $\mathrm{AFM}_{1}$ were found in the soft and hard cheese samples above those in the raw milk samples ; the cheese processing samples were the least contaminated (Amer and Ibrahim 2010). All positive raw milk and cheese samples have exceeded Egyptian regulation (free from $\mathrm{AFM}_{1}$ ), whereas they are all subject to US regulation (500 ng/l or $\mathrm{kg}$ ) and have exceeded European Commission regulations on all positive cheese samples and $52.6 \%$ of the raw milk samples examined $(50 \mathrm{ng} / \mathrm{l} \mathrm{or} \mathrm{kg}$ ).

Motawee (2013) studied the elevated levels of AFM in milk and milk products and found that the conversion of milk into Domiati cheese and the subsequent three-month storage period of this cheese reduced $\mathrm{AFM}_{1}$ levels overall by $64 \%$.

$\mathrm{AFM}_{1}$ can be detected in milk 12-24 $\mathrm{h}$ after the initial aflatoxin $\mathrm{B} 1$ ingestion, then $\mathrm{AFM}_{1}$ concentration in the milk decrease to an undetectable level within $72 \mathrm{~h}$ (Rahimi and Karim, 2008). Temperature and moisture were the most important factors in the amount of aflatoxin, as molds like Aspergillus flavus and Aspegillus parasititicus can grow easily in feed with moisture from $13 \%$ to $60 \%$ and environmental moisture from $50 \%$ to $60 \%$. (Kamkar et al. 2014). Furthermore, $\mathrm{AFM}_{1}$ pollution levels in dairy products may be attributable to the fact that forage and compoundstored feeds used during cold seasons are higher in APB1 
compared to feeds used during warm seasons, including fresh grass (Kamkar et al. 2014). The ratio of excreted $\mathrm{AFB}_{1}$ has been estimated to be $1-3 \%$ (Fallah 2010). $\mathrm{AFM}_{1}$ is also very stable and is not destroyed through storage or processing such as pasteurization, autoclaving or other techniques used to manufacture fluid milk and $\mathrm{AFM}_{1}$ could persist with the final products for human consumption if present in raw milk (Tajkarimi et al. 2008). Bakirci, (2001) reported that sterilizing milk at $121^{\circ} \mathrm{C}$ for 15 min degraded $\mathrm{AFM}_{1}$ by $12.21 \%$ and that boiling at $100{ }^{\circ} \mathrm{C}$ for $20 \mathrm{~min}$ decreased $\mathrm{AFM}_{1}$ by $14.50 \%$, the most efficient removal of AFB1 was achieved by heat-killed bacteria and concluded that destruction of $\mathrm{AFM}_{1}$ depends on time and temperature combination of the heat treatment applied. Fresh cow's milk at $121{ }^{\circ} \mathrm{C}$ sterilization resulted in a significant $\mathrm{AFM}_{1}$ decrease ( $\mathrm{p}<0.05$ ), of up to $58.8 \%$ (Omeiza et al., 2018).

The thermal bacteria can remove AFB1 as viable as bacteria, therefore a possible mechanism for metabolic degradation through viable bacteria in such experiments has been excluded. In this stage, the disappearance of aflatoxin could be due to binding of aflatoxin to the bacterial cell wall, a mechanism that other reports also suggested.

Recently, El-kest et al. (2015) highlighted the serious risk to public health since all age groups, including infants and children, consume milk and milk products worldwide. Milk and milk products therefore need to be monitored continuously for contamination with $\mathrm{AFM}_{1}$. It is also extremely important to maintain low levels of AFB1 in milk feed. (Bakirci 2001) reported that sterilizing milk at $121^{\circ} \mathrm{C}$ for 15 min degraded $\mathrm{AFM}_{1}$ by $12.21 \%$ and that boiling decreased $\mathrm{AFM}_{1}$ by $14.50 \%$, this destroying of $\mathrm{AFM}_{1}$ depends on the time and temperature combination of the heat treatment applied. Seasonal effects influence concentrations of $\mathrm{AFM}_{1}$, many authors have shown. The concentration of $\mathrm{AFM}_{1}$ is reported in cold seasons to be higher than in hot seasons, as in winter lactating cow food is fed by more mixed feeds that could be contaminated at higher AFB1 levels (Hussain and Anwar 2008; Tajkarimi et al. 2008; Bilandžić et al. 2010; Fallah 2010).

Many probiotic and LAB strains originated in fermented foods have been shown to inhibit both mould growth and mycotoxin production (ElShafei et al. 2010).

The present study investigated $\mathrm{AFM}_{1}$ contamination in raw milk, kareish cheese and yoghurt and studied the abilities of heating and probiotic bacteria to reduce $\mathrm{AFM}_{1}$ contamination in both raw milk and yoghurt.

\section{MATERIALS AND METHODS}

\section{Mould Isolation}

A $0.1 \mathrm{ml}$ aliquot of each sample dilution (milk, kareish cheese and yoghurt) was spread onto the surface of solidified Martin's medium Baruah and Barthakur (1997) and yeast extract-glucose-chloramphenicol-blue agar medium (YGCB agar). The petri dishes were incubated at $30 \pm 2^{\circ} \mathrm{C}$ for 5 days, and the colonies were then counted. Single mould colonies were removed, streaked on YM agar slants in test tubes, and stored at $4^{\circ} \mathrm{C}$ until use.

\section{Evaluation of the Toxigenic Potential of the Isolated Strains}

Two methods were used to assess the toxigenic potential: a medium-based qualitative system and highperformance liquid chromatography. Analyses for quantifying aflatoxin production were performed as follows:

\section{Qualitative assay}

This assay was performed according to the method of Dyer and McCammon (1994). In the case of an immediately prepared coconut agar, isolates of the Aspergillus flavus and related species have been developed for the detection of aflatoxin production. A. flavus isolates were detected more effectively than the synthetic medium, which included coconut cream $(50 \%)$ and agar $(1.5 \%)$, and were just as efficient as media containing desiccated coconut. Colonies produced on coconut cream agar were differentiated by fluorescence coloring to A. flavus from A. parasiticus and A. nomius. Furthermore, conidial colour of A. flavus and A. nomius was very different from that of A. parasiticus.

\section{Quantitative analysis of aflatoxin}

HPTLC was performed according to the method of Yuanling et al., (1996). HPTLC Separation Procedures. Chromatographic separations were performed on either $5 \mathrm{~cm}$ $\times 10 \mathrm{~cm}$ or $10 \mathrm{~cm} \times 10 \mathrm{~cm}$ HPTLC plates coated with silica gel 60 (E. Merck, Darmstadt, FRG). All plates were chromatographically washed three times with methanol and allowed to dry at room temperature prior to sample application. The plate prewash procedure was performed in order to reduce the fluorescence background from any adsorbed organic impurities on the plate. Quantitative TLC. Aliquots of $0.5 \mu \mathrm{L}$ of sample extracts were spotted onto a 5 $\mathrm{cm} \times 10 \mathrm{~cm}$ HPTLC plate adjacent to aliquots of standards ranging from 5 to $125 \mathrm{pg}$ for M1 per spot. The plate was then developed with anhydrous ethyl ether to remove the interfering compounds (direction 1) until the solvent front reached the top of the plate. The ethyl ether was evaporated, and the plate was examined by the CCD camera system. The top portion of the silica sorbent layer containing the interfering compounds, approximately $1 \mathrm{~cm}$, was scratched off. To separate the aflatoxin species, the plate was turned $180^{\circ}$ and developed with chloroform/acetone $(9: 1 \mathrm{v} / \mathrm{v})$ or chloroform/ethyl ether $(7: 3 \mathrm{v} / \mathrm{v})$ until the solvent front migrated to a distance of $7.5 \mathrm{~cm}$. The chromatographic images were obtained after the developed plate was dried in air for $5 \mathrm{~min}$.

\section{Effect of Heating on Aflatoxins \\ Milk sample inoculation}

$\mathrm{AFM}_{1}$-negative milk samples (total volume of approximately 10 1) were mixed, divided into 4 groups, and inoculated with $10,5,2.5$ or $1.25 \mathrm{ng} / \mathrm{kg} \mathrm{AFM}_{1}$ standard.

\section{Treatment of inoculated samples}

Twenty four samples of each group (raw milk, kareish cheese and yogurt) were used for aflatoxin detection in winter and summer season. Each group was divided into 3 subgroups of investigated samples (100 $\mathrm{ml}$ or $\mathrm{g}$ to each). The $1^{\text {st }}$ subgroup served as the control. The second subgroup was pasteurized at $65^{\circ} \mathrm{C}$ for $30 \mathrm{~min}$, followed by sudden cooling at $4^{\circ} \mathrm{C}$. The third subgroup was boiled at $100^{\circ} \mathrm{C}$ for $10 \mathrm{~min}$ (Shils, 1994).

\section{$\mathrm{AFM}_{1}$ Detoxification in Yoghurt by LAB \\ Culture activation}

LAB were obtained from the Christian Hansen (Chr. Hansen A/S laboratory, Copenhagen, Denmark). The cultures were activated in $11 \%$ reconstituted skim milk several times, and the last 3 activations were in strainspecific medium at $37^{\circ} \mathrm{C}$.

\section{LAB inoculum preparation}

Lactobacillus acidophilus $\mathrm{La}_{5}$ and Bifidobacterium lactis $B b_{12}$ were cultivated in $25 \mathrm{ml}$ of De Man Rogosa and 
Sharpe (MRS) broth and agar (Oxoid CM 359) at $37^{\circ} \mathrm{C}$ for $24 \mathrm{~h}$ (Oxoid manual, 1998). B. lactis was cultivated in $25 \mathrm{ml}$ of MRS broth (Oxoid 358 ) at $37^{\circ} \mathrm{C}$ for $24 \mathrm{~h}$. The suspensions were centrifuged at $1700 \times \mathrm{g}$ for $15 \mathrm{~min}$ under cooling $\left(10^{\circ} \mathrm{C}\right)$. The bacterial pellets were washed with phosphate saline buffered (PBS; pH 7.3, $0.01 \mathrm{M}$ ) twice and the supernatants were removed. The LAB and Bifidobacterium were counted using traditional plate counting and were adjusted to $3 \times 10^{8}$ and $7.6 \times 10^{6} \mathrm{cfu} / \mathrm{ml}$ bacteria per $4 \mathrm{ml}$ of PBS (per tube), respectively.

\section{Binding ability of LAB to $\mathrm{AFM}_{1}$}

To study the binding ability of LAB, L. acidophilus $\mathrm{La}_{5}(2 \%)$ and $\mathrm{B}$. lactis $B b_{12}(2 \%)$ were combined. A millilitre of a combination of $L$. acidophilus $L a_{5}(1 \%)$ and B. lactis $B b_{12} 1 \%$ ( $0.5 \mathrm{ml}$ of each) was suspended in separate Falcon tubes containing $49 \mathrm{ml}$ of commercial ultra-high temperature (UHT) skim milk naturally contaminated with $\mathrm{AFM}_{1}$ concentrations of 25,50 and $75 \mathrm{ng} / \mathrm{kg}$ and incubated at $37^{\circ} \mathrm{C}$ for $5 \mathrm{~h}$. The unbound content of $\mathrm{AFM}_{1}$ was determined by HPTLC analysis after 24,48 and $72 \mathrm{~h}$ in storage at $4 \pm 1^{\circ} \mathrm{C}$ according to AOAC (2005). The toxin was measured using HPTLC, and cell-free milk contaminated with aflatoxin was used as a positive control. Non-contaminated skim milk suspended bacteria have been used as a negative control (pure species), and all testing has taken place in triplicate (Mohamed 1998; Elsanhoty et al., 2014)

\section{Statistical analysis}

The experiments were conducted in triplicate and were statistically analyzed on triplicate samples using a computer program "SAS system for windows version 9.00 TS M0" (SAS 2008) for analysis of variance by one way (ANOVA) and comparison of means by Duncan's multiple comparison test where $\mathrm{P}<0.05$ was considered for significant difference

\section{RESULTS AND DISCUSSION}

Mould contamination not only deteriorates food and animal feed but also adversely affects human health. Moreover, fungi influence the biochemical character and flavour of the product, which often downgrades the product.

Table 1 shows the results from 72 milk and dairy product samples (cheese and yoghurt) tested for moulds that produce $\mathrm{AFM}_{1}$. Moulds producing $\mathrm{AFM}_{1}$ were found in $70.83 \%$ (17 of 24) of the raw milk samples. However, $91.67 \%$ (22 of 24) Kareish cheese samples were positive, and 12 of 24 yoghurt samples (50\%) were positive.

Table 1. Incidence of moulds producing aflatoxin $M_{1}$ in dairy and dairy products.

\begin{tabular}{|c|c|c|c|c|c|}
\hline \multirow{3}{*}{$\begin{array}{l}\text { Examined } \\
\text { samples }\end{array}$} & \multirow{3}{*}{$\begin{array}{c}\text { Total No. of } \\
\text { examined } \\
\text { samples }\end{array}$} & \multicolumn{4}{|c|}{ Moulds } \\
\hline & & \multicolumn{2}{|c|}{ Positive } & \multicolumn{2}{|c|}{ Negative } \\
\hline & & No. & $(\%)$ & No. & $(\%)$ \\
\hline$\overline{\operatorname{Raw}}$ & 24 & 17 & 70.83 & 7 & 29.17 \\
\hline Kareish cheese & 24 & 22 & 91.67 & 2 & 8.33 \\
\hline Yoghurt & 24 & 12 & 50.00 & 12 & 50.00 \\
\hline
\end{tabular}

\section{Aflatoxin in Raw Milk}

The data presented in Table 2 shows $\mathrm{AFM}_{1}$ occurrence and its levels (ng/kg) in both the summer and winter seasons of raw milk. $\mathrm{AFM}_{1}$ was detected in 10 of 12 samples from each season. $\mathrm{AFM}_{1}$ concentrations were higher during the winter season than during the summer, with average values of 311.8 and $207.0 \mathrm{ng} / \mathrm{kg}$ during the winter and summer, respectively.
These results are higher than those recommended by the European Union (European Commission, 2006). The standards of the European Union were followed by many other countries (Dashti et al. 2009). In Egypt 1990, the Ministry of Health set up raw milk and dairy products free of $\mathrm{AFM}_{1}$, and recently the maximum permissible levels comply with the EU standard. An increase of $\mathrm{AFM}_{1}$ in milk products and dairy products exceeding Codex limit may therefore affect international trade in these dairy products on global markets for any country, including Egypt.

The present results revealed that $\mathrm{AFM}_{1}$ concentrations in milk samples were higher in the winter than in the summer, which is consistent with the results of Tajkarimi et al. (2008), Who reported significantly higher levels of $\mathrm{AFM}_{1}$ in winter milk samples than in summer $(\mathrm{P}<0.05) ; 30 \%$ of winter samples were $>50 \mathrm{ng} / \mathrm{kg}$ and only $16 \%$ of summer samples were $>50 \mathrm{ng} / \mathrm{kg}$. One reason for this result is that milking animals are fed with greater amounts of mixed feed that may be contaminated at higher levels of AFB1 in winter season (Kamkar 2005; Hussain and Anwar 2008).

Table 2. Occurrence of aflatoxin $M_{1}$ in raw milk and its concentration (ng/kg) in summer and winter seasons.

\begin{tabular}{|c|c|c|c|c|}
\hline $\begin{array}{l}\text { Summer } \\
\text { season }\end{array}$ & $\begin{array}{c}\text { Milk } \\
\text { samples }\end{array}$ & $\begin{array}{c}\mathrm{AFM}_{1} \\
\text { (ng/kg) }\end{array}$ & $\begin{array}{l}\text { Winter } \\
\text { season }\end{array}$ & $\begin{array}{c}\mathrm{AFM}_{1} \\
\text { (ng/kg) }\end{array}$ \\
\hline \multirow{4}{*}{ June 2015} & 1 & $9.80^{\mathrm{h}} \pm 0.24$ & \multirow{4}{*}{$\begin{array}{c}\text { December } \\
2016\end{array}$} & $000.00^{\mathrm{K}} \pm 0.00$ \\
\hline & 2 & $86.2^{\mathrm{f}} \pm 0.55$ & & $100.90^{\mathrm{i}} \pm 0.50$ \\
\hline & 3 & $538.0^{\mathrm{a}} \pm 0.92$ & & $520.43^{c} \pm 0.44$ \\
\hline & 4 & $422.0^{\mathrm{b}} \pm 1.60$ & & $386.31^{\mathrm{f}} \pm 0.49$ \\
\hline \multirow{4}{*}{ July 2015} & 1 & $0.00^{i} \pm 0.00$ & \multirow{4}{*}{$\begin{array}{c}\text { January } \\
2017\end{array}$} & $78.600^{1} \pm 0.33$ \\
\hline & 2 & $66.73^{\mathrm{g}} \pm 1.04$ & & $246.05^{\mathrm{h}} \pm 0.78$ \\
\hline & 3 & $423.01^{\mathrm{b}} \pm 0.42$ & & $577.80^{\mathrm{b}} \pm 0.90$ \\
\hline & 4 & $309.4^{\mathrm{d}} \pm 0.57$ & & $392.40^{\mathrm{e}} \pm 1.33$ \\
\hline \multirow{4}{*}{$\begin{array}{l}\text { August } \\
2015\end{array}$} & 1 & $0.00^{1} \pm 0.00$ & \multirow{4}{*}{$\begin{array}{c}\text { February } \\
2016\end{array}$} & $00.000^{\mathrm{K}} \pm 0.00$ \\
\hline & 2 & $8.30^{\mathrm{h}} \pm 0.33$ & & $274.02^{\mathrm{g}} \pm 0.07$ \\
\hline & 3 & $339.5^{\mathrm{c}} \pm 1.59$ & & $698.30^{\mathrm{a}} \pm 0.57$ \\
\hline & 4 & $291.1^{\mathrm{e}} \pm 0.49$ & & $467.12^{d} \pm 0.51$ \\
\hline Mean & & 207 & & 311.8 \\
\hline LSD 0.05 & & 1.08 & & 1.64 \\
\hline $\mathrm{CV} \%$ & & 0.20 & & 0.47 \\
\hline F test & & $* *$ & & $* *$ \\
\hline$P$ value & & 0.000 & & 0.000 \\
\hline
\end{tabular}

From 1-4 of each season are different milk sample collected from traditional market in Egypt

*Data were expressed by means \pm SD $(n=24)$; Values in the same column with different letters were significantly different according to Duncan's test $(\mathbf{p}<0.05)$.

\section{Aflatoxin in Kareish cheese}

The data presented in Table 3 show the occurrence and concentration $(\mathrm{ng} / \mathrm{kg})$ of $\mathrm{AFM}_{1}$ in kareish cheese in both summer and winter seasons. $\mathrm{AFM}_{1}$ was detected in all the samples (24) obtained during both seasons. The highest values of $\mathrm{AFM}_{1}$ were 1295.0 and $1612.0 \mathrm{ng} / \mathrm{kg}$, and the lowest values were 32.56 and $36.57 \mathrm{ng} / \mathrm{kg}$ in the summer and winter, respectively. Clearly, the concentrations of $\mathrm{AFM}_{1}$ were lower in the summer than in the winter with average values of 527.4 versus $651.4 \mathrm{ng} / \mathrm{kg}$.

The present study revealed that $83.33 \%$ of the examined Kareish cheese samples (20 of 24) that exceeded the EU limits $(50 \mathrm{ng} / \mathrm{kg})$ and $70.83 \%$ of the examined cheese samples (17 of 24 samples) exceeded the Codex limits (500 $\mathrm{ng} / \mathrm{kg}$ ) in both the summer and winter. In Egypt in 1990, the ministry of health established that fluid milk and dairy products should be $\mathrm{AFM}_{1}$-free, and the current maximum permissible levels follow the European Union standard. 
A later study was done by (Amer and Ibrahim 2010) who investigate 150 cheese samples (fifty each of soft cheese, hard cheese and processed cheese) and found the average concentrations of $\mathrm{AFM}_{1}$ were higher in soft and hard cheese samples than in raw milk samples, while processed cheese samples were the less contaminated samples. All the positive cheese samples exceeded Egyptian regulations (free from $\mathrm{AFM}_{1}$ ), while all were within US regulations (500 ng/kg), and the EU Commission's regulations $(50 \mathrm{ng} / \mathrm{kg}$ ) exceeded al positive cheese samples and $52.6 \%$ of crude milk samples. Another study in Egypt found that the $\mathrm{AFM}_{1}$ content in kareish cheese samples ranged from 5000 to $35,000 \mathrm{ng} / \mathrm{kg}$, with a mean value of $17,500 \mathrm{ng} / \mathrm{kg}$ (El-Diasty and Salem 2007). In addition, soft cheese (fresh kareish and Domiati) samples have been examined, and the mean values were 3600 and 67,000 ng/kg, respectively (Awad et al. 2014), while other researchers detected no aflatoxins in some cheese samples ( Sessou et al. 2013; Fontaine et al. 2015).

Table 3. Occurrence of aflatoxin $M_{1}$ in kareish cheese and its concentration (ng/kg) in summer and winter seasons.

\begin{tabular}{|c|c|c|c|c|}
\hline $\begin{array}{l}\text { Summer } \\
\text { season }\end{array}$ & $\begin{array}{c}\text { Kareish } \\
\text { cheese } \\
\text { samples }\end{array}$ & $\begin{array}{l}\text { AFM1 } \\
\text { (ng/kg) }\end{array}$ & $\begin{array}{l}\text { Winter } \\
\text { season }\end{array}$ & $\begin{array}{l}\text { AFM1 } \\
\text { (ng/kg) }\end{array}$ \\
\hline \multirow{4}{*}{$\begin{array}{l}\text { June } \\
2016\end{array}$} & 1 & $487.20^{\mathrm{f}} \pm 0.57$ & \multirow{4}{*}{$\begin{array}{c}\text { December } \\
2016\end{array}$} & $36.570 \pm 0.35$ \\
\hline & 2 & $591.30^{\mathrm{d}} \pm 0.49$ & & $239.15^{\mathrm{i}} \pm 0.69$ \\
\hline & 3 & $1295.0^{\mathrm{a}} \pm 1.59$ & & $588.00^{\mathrm{e}} \pm 1.63$ \\
\hline & 4 & $762.45^{\mathrm{c}} \pm 0.49$ & & $467.04^{\mathrm{g}} \pm 0.85$ \\
\hline & 1 & $46.11^{\mathrm{k}} \pm 0.74$ & & $184.36^{\mathrm{k}} \pm 0.56$ \\
\hline July & 2 & $392.25^{\mathrm{i}} \pm 0.61$ & January & $326.35^{\mathrm{h}} \pm 1.37$ \\
\hline \multirow[t]{3}{*}{2016} & 3 & $856.09^{\mathrm{b}} \pm 0.51$ & 2017 & $1612.0^{\mathrm{a}} \pm 2.41$ \\
\hline & 4 & $458.00^{\mathrm{g}} \pm 1.61$ & & $755.09^{\mathrm{d}} \pm 0.44$ \\
\hline & 1 & $32.56 \pm 0.35$ & & $227.64^{\mathrm{j}} \pm 0.29$ \\
\hline August & 2 & $388.50^{\mathrm{j}} \pm 0.41$ & February & $479.40^{\mathrm{f}} \pm 0.45$ \\
\hline \multirow[t]{2}{*}{2016} & 3 & $566.70^{\mathrm{e}} \pm 0.42$ & $2017^{\circ}$ & $1535.0^{\mathrm{b}} \pm 0.31$ \\
\hline & 4 & $453.65^{\mathrm{h}} \pm 1.08$ & & $1365.7^{\mathrm{c}} \pm 0.25$ \\
\hline$\overline{\text { Mean }}$ & & 527.4 & & 651.4 \\
\hline \multicolumn{5}{|l|}{ LSD 0.05} \\
\hline \multicolumn{5}{|l|}{$\mathrm{CV} \%$} \\
\hline$F$ test & & $* *$ & & $* *$ \\
\hline $\mathrm{P}$ value & & 0.000 & & 0.000 \\
\hline
\end{tabular}

From 1-4 of each season are different Kareish cheese sample collected from traditional market in Egypt,

*Data were expressed by means \pm SD $(n=24)$; Values in the same column with different letters were significantly different according to Duncan's test $(\mathbf{p}<\mathbf{0 . 0 5})$.

\section{$\mathrm{AFM}_{1}$ in Yoghurt}

The data presented in Table 4 show the occurrence of $\mathrm{AFM}_{1}$ in yoghurt and the $\mathrm{AFM}_{1}$ concentrations (ng/kg) during both the summer and winter seasons. In the summer season, the highest $\mathrm{AFM}_{1}$ concentration was $66.05 \mathrm{ng} / \mathrm{kg}$, while the lowest concentration was $31.46 \mathrm{ng} / \mathrm{kg}$, and $\mathrm{AFM}_{1}$ was not detected in 3 of 12 samples. In the winter, the highest $\mathrm{AFM}_{1}$ concentration was $84.14 \mathrm{ng} / \mathrm{kg}$, while the lowest $\mathrm{AFM}_{1}$ concentration was $56.60 \mathrm{ng} / \mathrm{kg}$, and $\mathrm{AFM}_{1}$ was not detected in 1 of 12 samples (Table 4).

Several surveys have been performed to determine $\mathrm{AFM}_{1}$ levels in yoghurt. Approximately $80 \%$ of all yoghurt samples in Italy were contaminated with $\mathrm{AFM}_{1}$, ranging from $1-3.1 \mathrm{ng} / \mathrm{kg}$ (Galvano et al. 1998). A further study found that 61.0 per cent of the yogurt samples had lower levels of $\mathrm{AFM}_{1}$ than the previous survey.(Galvano et al. 2001). Forty eight yoghurt samples have been tested in Portugal, while only 2 (4.2\%) have been contaminated by $0.45 \mathrm{ng} / \mathrm{kg} \mathrm{AFM}$. Most yoghurt samples $(62.88 \%)$ purchased at different markets in
Ankara were free of $\mathrm{AFM}_{1}$ Sarımehmetoglu et al. (2004), while elsewhere in Turkey, $65.38 \%$ of ordinary yoghurt samples, $33.33 \%$ of fruit yoghurt samples, and $55.77 \%$ of strained yoghurt samples contained aflatoxin (Akkaya et al. 2006). Another study found $\mathrm{AFM}_{1}$ in $2.8 \%$ of yoghurt samples (Cano-Sancho et al. 2010). The levels of $\mathrm{AFM}_{1}$ contamination in locally produced yoghurt appear to vary across studies. The different explanations for these variations include varying yoghurt manufacturing procedures, different milk contamination levels, yoghurt type, yoghurt ripening conditions, geographical region, the season and analytical methods employed (Guan et al. 2011).

Various $\mathrm{AFM}_{1}$ content increases in yogurt associated with milk were detected (Bakirci 2001). Govaris et al., (2002) evaluated fermentation effects and found that levels of $\mathrm{AFM}_{1}$ have been significantly reduced in all samples of yogurt from those that were initially in the milk. Factors like low $\mathrm{pH}$, organic acid formation and other fermentation by-products, and the presence of $\mathrm{LAB}$, were attributable to this decrease in $\mathrm{AFM}_{1}$. During fermentation the low $\mathrm{pH}$ alters dairy proteins structure, like caseins, leading to yogurt and cheese coagulum formation. These results were agreed with that obtained by Megalla and Hafez (1982) who concluded that the $\mathrm{pH}$ may contribute to the transformation of AFB1 to the non-toxic AFB2 in acidogenous yogurt. The fermentation of yoghurt and acidified milk containing AFB1 also significantly decreased the toxin level, accordingly (Rasic et al, 1991). The proportional link between both the degradation in $\mathrm{pH}$ values and the corresponding decline of aflatoxins, i.e. a further decrease in $\mathrm{pH}$ value and a further declines in the level of aflatoxins in Yogurt was established by (Motawee and Abd El-Ghany 2011).

Table 4. Occurrence of aflatoxin $M_{1}$ in yoghurt and its concentration $(\mathrm{ng} / \mathrm{kg})$ in summer and winter seasons

\begin{tabular}{|c|c|c|c|c|}
\hline $\begin{array}{l}\text { Summer } \\
\text { season }\end{array}$ & $\begin{array}{l}\text { Yoghurt } \\
\text { samples }\end{array}$ & $\begin{array}{l}\text { AFM1 } \\
\text { (ng/kg) }\end{array}$ & $\begin{array}{l}\text { Winter } \\
\text { season }\end{array}$ & $\begin{array}{l}\text { AFM1 } \\
\text { (ng/kg) }\end{array}$ \\
\hline \multirow{4}{*}{ June 2016} & 1 & $00.00^{ \pm} \pm 0.00$ & \multirow{4}{*}{$\begin{array}{c}\text { December } \\
2016\end{array}$} & $000.00 \pm 0.00$ \\
\hline & 2 & $55.07^{ \pm} \pm 0.35$ & & $56.60^{\mathrm{k}} \pm 0.24$ \\
\hline & 3 & $66.05^{\mathrm{a}} \pm 0.36$ & & $77.13^{\mathrm{d}} \pm 0.31$ \\
\hline & 4 & $56.89^{\mathrm{d}} \pm 0.33$ & & $65.50^{\mathrm{g}} \pm 0.33$ \\
\hline \multirow{4}{*}{ July 2016} & 1 & $00.00^{1} \pm 0.00$ & \multirow{4}{*}{$\begin{array}{c}\text { January } \\
2017\end{array}$} & $62.96^{\mathrm{h}} \pm 0.29$ \\
\hline & 2 & $46.23^{\mathrm{g}} \pm 0.64$ & & $59.84^{j} \pm 0.23$ \\
\hline & 3 & $62.06^{\mathrm{b}} \pm 0.42$ & & $84.14^{\mathrm{a}} \pm 0.22$ \\
\hline & 4 & $58.33^{\mathrm{c}} \pm 0.41$ & & $74.08^{\mathrm{f}} \pm 0.33$ \\
\hline \multirow{4}{*}{$\begin{array}{l}\text { August } \\
2016\end{array}$} & 1 & $00.00^{\prime} \pm 0.00$ & \multirow{4}{*}{$\begin{array}{c}\text { February } \\
2017\end{array}$} & $60.72^{1} \pm 0.22$ \\
\hline & 2 & $31.46^{1} \pm 0.44$ & & $75.39^{\mathrm{e}} \pm 0.40$ \\
\hline & 3 & $51.66^{t} \pm 0.29$ & & $82.90^{\mathrm{b}} \pm 0.17$ \\
\hline & 4 & $41.85^{\mathrm{h}} \pm 0.26$ & & $79.85^{\mathrm{c}} \pm 0.56$ \\
\hline \multirow{3}{*}{\multicolumn{5}{|c|}{$\begin{array}{l}\text { Mean } \\
\text { LSD } 0.05 \\
\text { CV\% }\end{array}$}} \\
\hline & & & & \\
\hline & & & & \\
\hline \multicolumn{5}{|l|}{ F test } \\
\hline$P$ value & & 0.000 & & 0.000 \\
\hline
\end{tabular}

From 1-4 of each season are different Yoghurt sample collected from traditional market in Egypt

*Data were expressed by means \pm SD $(n=24)$; Values in the same column with different letters were significantly different according to Duncan's test $(p<0.05)$.

\section{Aflatoxin control}

Two treatments were applied to reduce $\mathrm{AFM}_{1}$ concentrations in raw milk and a milk product (yoghurt), including heating (boiling and pasteurization) and probiotic bacteria.

\section{Effect of heating}

Table 5 shows the mean concentration $(\mathrm{ng} / \mathrm{kg})$ and detoxification (\%) of $\mathrm{AFM}_{1}$ in different treated milk samples. 
Clearly, applying heat reduced the $\mathrm{AFM}_{1}$ concentrations in all the raw milk samples. These results revealed that pasteurization reduced $\mathrm{AFM}_{1}$ concentrations in the raw milk samples by an average of $15.45 \%$, ranging from 10.0 to $22.6 \%$, while boiling reduced $\mathrm{AFM}_{1}$ by an average of $26.7 \%$, ranging from 25.47 to 28.57

Table 5. The mean concentration (ng/kg) and detoxification $(\%)$ of aflatoxin $M_{1}$ in different treated milk samples

\begin{tabular}{|c|c|c|c|c|c|}
\hline \multirow[b]{2}{*}{$\begin{array}{l}\text { Initial } \\
\text { AFM1 } \\
\text { levels } \\
\text { (ng/kg) }\end{array}$} & \multirow[b]{2}{*}{$\begin{array}{c}\text { Positive } \\
\text { control } \\
\text { levels } \\
\text { (ng/kg) }\end{array}$} & \multicolumn{2}{|c|}{$\begin{array}{c}\text { Pasteurization } \\
\text { treatments }\end{array}$} & \multicolumn{2}{|c|}{$\begin{array}{c}\text { Boiling } \\
\text { treatments }\end{array}$} \\
\hline & & 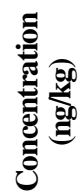 & 㺼 & 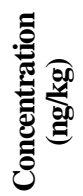 & 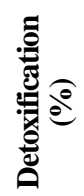 \\
\hline Group I (10) & $9.4 \mathrm{a}$ & $8.00 \mathrm{a}$ & 14.9 & $6.90 \mathrm{a}$ & 26.60 \\
\hline Group II (5.00) & $4.2 \mathrm{~b}$ & $3.60 \mathrm{~b}$ & 14.3 & $3.10 \mathrm{~b}$ & 26.19 \\
\hline Group III (2.50) & $2.1 \mathrm{c}$ & $1.89 \mathrm{c}$ & 10.0 & $1.50 \mathrm{c}$ & 28.57 \\
\hline Group IV (1.25) & $1.06 \mathrm{~d}$ & $0.82 \mathrm{~d}$ & 22.6 & $0.79 \mathrm{~d}$ & 25.47 \\
\hline Average & 4.19 & 3.58 & 15.45 & 3.07 & 26.71 \\
\hline
\end{tabular}

* Values in the same column with different letters were significantly different according to Duncan's test $(p<0.05)$.

The present results are in good agreement with Choudhary et al. (1998), who reported that sterilizing milk at $121^{\circ} \mathrm{C}$ for 15 min caused a $12.21 \%$, degradation of $\mathrm{AFM}_{1}$, while boiling at $100{ }^{\circ} \mathrm{C}$ for 20 minutes decreased the concentration of $\mathrm{AFM}_{1}$ destruction by $14.50 \%$ according to a time and temperature thermal processing combination. A significant reduced level $(\mathrm{p}<0.05)$ of $\mathrm{AFM}_{1}$ by up to $58.8 \%$ was achieved when fresh cow's milk was sterilized at $121^{\circ} \mathrm{C}$ for 15 min (Omeiza et al., 2018). Additionally, Bakirci, (2001) found that pasteurization decreased $\mathrm{AFM}_{1}$ levels in milk at the rate of $7.62 \%$. Also, UHT milk contamination levels were lower than those in raw milk. Based on the idea that heating or storing at lower temperatures does not appreciably change $\mathrm{AFM}_{1}$ levels Prandini et al. (2009), many authors have shown that seasonal effects do influence $\mathrm{AFM}_{1}$ concentrations.

Therefore, the heat treatment of milk may be critical for reducing $\mathrm{AFM}_{1}$ levels and subsequently diminishing the dangers of this toxin to public health.

\section{Effects of probiotic bacteria}

Various species of primarily Lactobacillus and Bifidobacterium have historically been used as probiotics (Shahin 2007; Ranadheera et al. 2010).

Table 6 lists the results for two strains of LAB, $L$. acidophilus and $B$. lactis that were tested for $\mathrm{AFM}_{1}$ reduction in milk contaminated with $25 \mathrm{ng} / \mathrm{kgAFM}_{1}$. The level of toxin was clearly gradually reduced as a function of time, and the toxin was completely eliminated by the end of the refrigerated storage period ( 3 days), where $L$. acidophilus and B. lactis were better able to remove $\mathrm{AFM}_{1}$. After one day, the $\mathrm{AFM}_{1}$ concentration decreased to $17.8 \mathrm{ng} / \mathrm{kg}$ (28.8\%), 10.4 $\mathrm{ng} / \mathrm{kg}(58.4 \%)$ and $5.6 \mathrm{ng} / \mathrm{kg}(77.6 \%)$ in the presence of $L$. acidophilus $(2 \%)$, B. lactis $(2 \%)$ and the combination of $L$. acidophilus $(1 \%)$ and $B$. lactis $(1 \%)$, respectively. The most extensive reductions of the $\mathrm{AFM}_{1}$ concentration to $8.6 \mathrm{ng} / \mathrm{kg}$ (65.6\%), $6.9 \mathrm{ng} / \mathrm{kg}(72.4 \%)$ and $1.2 \mathrm{ng} / \mathrm{kg}(95.2 \%)$ were achieved using the same previous concentrations of LAB strains after $48 \mathrm{~h}$. No $\mathrm{AFM}_{1}$ was detected on the third day.

The two strains of LAB (L. acidophilus and B. lactis) were also tested for $\mathrm{AFM}_{1}$ reduction in milk contaminated with 50 and $75 \mathrm{ng} / \mathrm{kg} \mathrm{AFM}$. The data indicate that after one day, the $\mathrm{AFM}_{1}$ concentration $(50 \mathrm{ng} / \mathrm{kg}$ ) decreased to 37.5 $\mathrm{ng} / \mathrm{kg}$ (25.0\%), $24.4 \mathrm{ng} / \mathrm{kg}(51.2 \%)$ and $17.3 \mathrm{ng} / \mathrm{kg}(75.4 \%)$, while the concentration $(75 \mathrm{ng} / \mathrm{kg}$ ) was reduced to $62.7 \mathrm{ng} / \mathrm{kg}$ (16.4\%), $51.5 \mathrm{ng} / \mathrm{kg}(31.3 \%)$ and $32.8 \mathrm{ng} / \mathrm{kg}(56.3 \%)$ in the presence of L. acidophilus $(2 \%), B$. lactis $(2 \%)$ and the combination of L. acidophilus (1\%) and B. lactis (1\%), respectively. The most extensive reductions of the $\mathrm{AFM}_{1}$ concentration $(50 \mathrm{ng} / \mathrm{kg})$ to $13.6 \mathrm{ng} / \mathrm{kg}(72.8 \%), 5.9 \mathrm{ng} / \mathrm{kg}$ $(88.2 \%)$ and $2.6 \mathrm{ng} / \mathrm{kg}(94.4 \%)$, no $\mathrm{AFM}_{1}$ was detected on the third day. While, the $\mathrm{AFM}_{1}$ concentration $(75 \mathrm{ng} / \mathrm{kg})$ to $41.8 \mathrm{ng} / \mathrm{kg}$ (45.3\%), $22.6 \mathrm{ng} / \mathrm{kg}(69.9 \%)$ and $7.12 \mathrm{ng} / \mathrm{kg}$ $(92.8 \%)$ respectively were achieved using the same concentrations of LAB strains after $48 \mathrm{~h}$. $\mathrm{AFM}_{1}$ not detected in the treatment containing the combination of L. acidophilus $(1 \%)$ and $B$. lactis $(1 \%)$ on the third day; however, the $\mathrm{AFM}_{1}$ concentration was reduced by $L$. acidophilus to $28.2 \mathrm{ng} / \mathrm{kg}$ (62.4\%) and by B. lactis to $3.90 \mathrm{ng} / \mathrm{kg}(94.8 \%)$.

Table 6. Reduction of Aflatoxin $M_{1}(25,50$ and $75 \mathrm{ng} / \mathrm{kg})$ in milk using Lactobacillus acidophilus (La $)$ and Bifidobacterium lactis $\left(\mathbf{B b}_{12}\right)$

\begin{tabular}{|c|c|c|c|c|c|c|c|c|c|}
\hline Treatment & & Contro & & Lactobacillus & ophilus & Bifidobacterit & lactis & $\left(\mathbf{L a}_{5}\right)+(1$ & $\left(\mathrm{b}_{12}\right)$ \\
\hline Days & $\begin{array}{c}\mathrm{AFMM_{1 }} \\
\text { (ng/kg) }\end{array}$ & $\begin{array}{c}\text { Reduction of } \\
\text { AFM }_{1}\end{array}$ & $(\%)$ & $\begin{array}{c}\text { Reduction of } \\
\text { AFM }_{1}\end{array}$ & $(\%)$ & $\begin{array}{c}\text { Reduction of } \\
\text { AFM }_{1}\end{array}$ & $(\%)$ & $\begin{array}{c}\text { Reduction } \\
\text { of } \text { AFM }_{1}\end{array}$ & $(\%)$ \\
\hline 1 & 25 & $22.7^{\mathrm{g}} \pm 0.18$ & 9.2 & $17.8^{\mathrm{e}} \pm 0.08$ & 28.8 & $10.4^{\mathrm{a}} \pm 0.08$ & 58.4 & $5.6^{\mathrm{a}} \pm 0.09$ & 77.6 \\
\hline 2 & 25 & $12.2^{\mathrm{n}} \pm 0.15$ & 51.2 & $8.6^{\mathrm{g}} \pm 0.13$ & 65.6 & $6.9^{\mathrm{e}} \pm 0.13$ & 72.4 & $1.2^{\mathrm{I}} \pm 0.04$ & 95.2 \\
\hline 3 & 25 & $7.8^{1} \pm 0.11$ & 68.8 & $\mathrm{ND}^{\mathrm{n}} \pm 0.00$ & 100 & $\mathrm{ND}^{\mathrm{n}} \pm 0.00$ & 100 & $\mathrm{ND}^{\mathrm{g}} \pm 0.00$ & 100 \\
\hline 1 & 50 & $48.9^{\mathrm{a}} \pm 0.32$ & 2.2 & $37.5^{\mathrm{c}} \pm 0.18$ & 25.0 & $24.4^{\mathrm{D}} \pm 0.40$ & 51.2 & $17.3^{\mathrm{D}} \pm 0.18$ & 65.4 \\
\hline 2 & 50 & $44.3^{\mathrm{e}} \pm 0.19$ & 11.4 & $13.6^{\mathrm{t}} \pm 0.24$ & 72.8 & $5.9^{\mathrm{i}} \pm 0.08$ & 88.2 & $2.6^{\mathrm{e}} \pm 0.18$ & 94.4 \\
\hline 3 & 50 & $39.8^{\mathrm{t}} \pm 0.17$ & 20.4 & $\mathrm{ND}^{\mathrm{n}} \pm 0.00$ & 100 & $\mathrm{ND}^{\mathrm{n}} \pm 0.00$ & 100 & $\mathrm{ND}^{\mathrm{g}} \pm 0.00$ & 100 \\
\hline 1 & 75 & $72.4^{\mathrm{a}} \pm 0.22$ & 3.5 & $62.7^{\mathrm{a}} \pm 0.16$ & 16.4 & $51.5^{\mathrm{a}} \pm 0.19$ & 31.3 & $32.8^{\mathrm{a}} \pm 0.20$ & 56.3 \\
\hline 2 & 75 & $70.1^{\mathrm{b}} \pm 0.25$ & 6.5 & $41.8^{\mathrm{b}} \pm 0.12$ & 45.3 & $22.6^{c} \pm 0.16$ & 69.9 & $7.12^{\mathrm{c}} \pm 0.22$ & 92.8 \\
\hline 3 & 75 & $68.6^{\mathrm{c}} \pm 0.16$ & 8.5 & $28.2^{\mathrm{a}} \pm 0.13$ & 62.4 & $3.90^{\mathrm{g}} \pm 0.10$ & 94.8 & $\mathrm{ND}^{\mathrm{g}} \pm 0.00$ & 100 \\
\hline Mean & & 42.97 & & 23.35 & & 13.96 & & 7.40 & \\
\hline $\begin{array}{l}\text { CV\% } \\
\text { F test }\end{array}$ & & $* *$ & & 0000 & & & & & \\
\hline F test & & 0000 & & 0.000 & & $* *$ & & $* *$ & \\
\hline $\mathrm{P}$ value & & 0.000 & & & & 0.000 & & 0.000 & \\
\hline
\end{tabular}

\section{ND: Not Detected}

*Data were expressed by means \pm SD $(n=12)$; Values in the same column with different letters were significantly different according to Duncan's test $(\mathbf{p}<0.05)$.

Concerning the effect of $\mathrm{LAB}$ on reducing the concentration of $\mathrm{AFM}_{1}$, these results are consistent with those reported by Mohamed, (1998), who measured reductions of
$\mathrm{AFM}_{1}$ in yogurt prepared with 95,3\% L. acidophilus , and $84,7 \%$ Bifidobacterium bifidum after 5 days. The same conclusion was reached when different species of LAB were 
used, and the reduction level by these strains ranged from 26.2-34.0\% depending upon the bacterial isolates (Emara et al. 2000). Regarding $\mathrm{AFM}_{1}$ stability in the cold, El Khoury et al. (2011) found that the LAB (L. bulgaricus and $S$. thermophilus strains) used in Lebanese dairy industries effectively reduced $\mathrm{AFM}_{1}$ concentration in liquid culture media and during yoghurt processing. $\mathrm{LAB}$ thus seems to play a key part in removing $\mathrm{AFM}_{1}$ and could be employed in the reduction of $\mathrm{AFM}_{1}$ levels as a biological agents. Results obtained in this study showed that all of the LABs and bifidobacteria under this study are capable to bind $\mathrm{AFM}_{1}$.

\section{CONCLUSION}

Raw milk, kareish cheese and yoghurt were assessed for their contamination with aflatoxin $\left(\mathrm{AFM}_{1}\right)$. The occurrence and concentrations of AFM1 varied with product type and season of the year. The concentration of toxin in $83.33 \%$ of the examined cheese samples were exceeded the EU limit (50 ng/kg) and $70.83 \%$ of these samples exceeded the Codex limit $(500 \mathrm{ng} / \mathrm{kg}$ ) during both seasons. The combination of both probiotic bacteria ( $L$. acidophilus and $B$. lactis) was better able to reduce $\mathrm{AFM}_{1}$ in milk by $78 \%$ after one day of incubation. It could be concluded that the effect of both heat treatment and probiotics differed with the initial level of $\mathrm{AFM}_{1}$ concentration.

Funding

This work is based on the research supported by Zagazig university, agriculture faculty department of food science

\section{Compliance with ethical standards \\ Conflict of interest}

The authors declare that they have no conflict of interest. animals

Research involving human participants and/or

N/A. This research did not involve human participants and/or animals.

\section{Informed consent} participants.

N/A. This research did not involve human

\section{REFERENCES}

Akkaya L, Birdane YO, Oguz H, Cemek M (2006) Occurrence of aflatoxin $\mathrm{M} \sim 1$ in yogurt samples from Afyonkarahisar, Turkey Bulletin-Veterinary Institute in Pulawy 50:517

Amer AA, Ibrahim ME (2010) Determination of aflatoxin M1 in raw milk and traditional cheeses retailed in Egyptian markets Journal of Toxicology and Environmental Health Sciences 2:50-52

AOAC Official Method 2000.08. (2005). Natural toxinschapter 49 (18th ed.). In Official Methods of Analysis of AOAC InternationalAflatoxin M1 in liquid milk, immunoaffinity column by liquid chromatography (pp. 45e47). Gaithersburg, Maryland 20877-2417, USA: AOAC International.

Awad EI, Mansour IHAH, Ismail S-EY (2014) Qualitative and Quantitative Detection of Aflatoxin M1 Residues in White Soft Cheese Alexandria Journal of Veterinary Sciences 40:119-123

Bakirci I (2001) A study on the occurrence of aflatoxin M1 in milk and milk products produced in Van province of Turkey Food control 12:47-51

Baruah T, Barthakur H (1997) A Textook of Soil Chemical Analysis Vikash, New Delhi
Bilandžić N, Varenina I, Solomun B (2010) Aflatoxin M 1 in raw milk in Croatia Food Control 21:1279-1281

Cano-Sancho G, Marin S, Ramos AJ, Peris-Vicente J, Sanchis V (2010) Occurrence of aflatoxin M1 and exposure assessment in Catalonia (Spain) Revista Iberoamericana de Micología 27:130-135

Choudhary P, Sharma R, Borkhateria V (1998) Carry-over of aflatoxin B1 from feed as aflatoxin M1 in milk of Indian cows Milchwissenschaft 53:513-515

Dashti B, Al-Hamli S, Alomirah H, Al-Zenki S, Abbas AB, Sawaya W (2009) Levels of aflatoxin M1 in milk, cheese consumed in Kuwait and occurrence of total aflatoxin in local and imported animal feed Food Control 20:686-690

Dyer SK, McCammon S (1994) Detection of toxigenic isolates of Aspergillus flavus and related species on coconut cream agar Journal of Applied Bacteriology 76:75-78

Egyptian Regulations. 1990. Maximum Limits for Mycotoxin in Foods. Part L Aflatoxins E.S.1875-1990

El-Diasty EM, Salem R (2007) Incidence of lipolytic and proteolytic fungi in some milk products and their public health significance J Appl Sci Res 3:1684-1688

El-kest MM, El-Hariri M, Khafaga N, Refai MK (2015) Studies on Contamination of Dairy Products by Aflatoxin M1 and Its Control by Probiotics J Glob Biosci 4:1294-1312

El Khoury A, Atoui A, Yaghi J (2011) Analysis of aflatoxin M1 in milk and yogurt and AFM1 reduction by lactic acid bacteria used in Lebanese industry Food Control 22:1695-1699

Elsanhoty, RM, Salam, SA, Ramadan, MF and Badr FH (2014) Detoxification of aflatoxin M1 in yoghurt using probiotics and lactic acid bacteria Food Control 43: $129-134$

ElShafei GM, El-Said M, Attia HA, Mohammed T (2010) Environmentally friendly pesticides: Essential oilbased w/o/w multiple emulsions for anti-fungal formulations Industrial crops and products 31:99-106

Emara H, Bean G, Trucksess M (2000) Detoxification of aflatoxin M1 on lactic acid bacteria in contaminated with it milk J Agric Sci Mansoura Univ Egypt 25:945-953

European Commission. (2006). Commission Regulation (EC) No. 1881/2006 of 19 December 2006-setting maximum levels for certain contaminants in foodstuffs. Regulation (EC) 401/2006 on the official control of the levels of mycotoxins in foodstuffs ttp://eurlex.europa.eu/ Lex UriServ / Lex Uri Serv. do? uri0 CONSLEG: 2006 R1881: 20100701: PT:PDF Accessed 10.08.13.

Fallah AA (2010) Aflatoxin M 1 contamination in dairy products marketed in Iran during winter and summer Food control 21:1478-1481

Fontaine K et al. (2015) Occurrence of roquefortine C, mycophenolic acid and aflatoxin M1 mycotoxins in blue-veined cheeses Food Control 47:634-640

Galvano F, Galofaro V, DE ANGELIS A, Galvano M, Bognanno M, Galvano G (1998) Survey of the occurrence of aflatoxin $\mathrm{M} 1$ in dairy products marketed in Italy Journal of Food Protection 61:738-741

Galvano F, Galofaro V, Ritieni A, Bognanno M, De Angelis A, Galvano G (2001) Survey of the occurrence of aflatoxin M1 in dairy products marketed in Italy: second year of observation Food Additives and Contaminants 18:644-646

Govaris A, Roussi V, Koidis P, Botsoglou N (2002) Distribution and stability of aflatoxin M1 during production and storage of yoghurt Food Additives and Contaminants 19:1043-1050 
Guan D, Li P, Zhang Q, Zhang W, Zhang D, Jiang J (2011) An ultra-sensitive monoclonal antibody-based competitive enzyme immunoassay for aflatoxin M1 in milk and infant milk products Food Chemistry 125:1359-1364

Hussain I, Anwar J (2008a) A study on contamination of aflatoxin M1 in raw milk in the Punjab province of Pakistan Food control 19:393-395

Ito Y, Peterson SW, Wicklow DT, Goto T (2001) Aspergillus pseudotamarii, a new aflatoxin producing species in Aspergillus section Flavi Mycol Res 105:233-239

Kamkar A (2005) A study on the occurrence of aflatoxin M1 in raw milk produced in Sarab city of Iran Food control 16:593-599

Kamkar A, Fallah A, Mozaffari Nejad A S (2014) The review of aflatoxin M1 contamination in milk and dairy products produced in Iran. Toxin Review 33: 160-168.

Megalla S E, Hafez A H (1982) Detoxification of aflatoxin B1 acidogenous yoghurt Mycopathologia 77: 89-91.

Mohamed O (1998) Stability of AFM1 and AFB1 in yoghurt manufactured by Lactobacills Acidophilus and Bifidobacterium bifidum. Al-Azhar J Agric Res 27:104-120

Motawee M (2013) Reduction of aflatoxin M1 content during manufacture and storage of Egyptian domaiti cheese International Journal of Veterinary Medicine: Research and Reports 2013:207299

Motawee MM, Abd El-Ghany MA, (2011) Effect of Some Lactic Acid Bacteria Strains on Aflatoxins Reduction in Some Dairy Foods. The 6thArab and 3rd International Annual Scientific Conference, Faculty of Specific Education Mansoura University - Egypt April 13-14

Motawee MM, Bauer J, McMahon DJ (2009) Survey of aflatoxin M1 in cow, goat, buffalo and camel milks in Ismailia-Egypt Bull Environ Contam Toxicol 83:766769.

No E (2006) Setting maximum levels for certain contaminants in foodstuffs Official Journal of the European Union L 364

Omeiza G K, Mwanza M, Enem S I, Godwin E, Adeiza M A, Okoli C (2018) Reducing Efficiencies of the Commonly Used Heat Treatment Methods and Fermentation Processes on Aflatoxin M1 in Naturally Contaminated Fresh Cow Milk Open Journal of Veterinary Medicine 8: 134-145
Oxoid manual (1998) The Oxoid manual of culture media: Oxoid Limited, Basiugtoke, Hampshire, England.

Prandini A, Tansini G, Sigolo S, Filippi L, Laporta M, Piva G (2009) On the occurrence of aflatoxin M1 in milk and dairy products Food and chemical toxicology 47:984991

Rahimi E, Karim G (2008) Determination of aflatoxin M1 in raw milk producing in dairy farmsin Chahar-MahalBakhtiari province using ELISA Journal of Food Science and Technology 5: 51-59.

Ranadheera R, Baines S, Adams M (2010) Importance of food in probiotic efficacy Food research international 43:1-7

Rasic J L, Skrinjar M, Markov S (1991) Decrease of aflatoxin B1 in yoghurt and acidified milk Mycopathologia 113: 117-119.

Sarımehmetoglu B, Kuplulu O, Celik TH (2004) Detection of aflatoxin M1 in cheese samples by ELISA Food control 15:45-49

SAS S. (2008) STAT 9.2 User's Guide. Version 9.2. Cary, NC: SAS Institute. Inc.

Sessou P, Farougou S, Yèhouenou B, Agbangnan P, Azokpota P, Youssao I, Sohounhloue D (2013) Investigation on aflatoxin M1 content of traditional cheese wagashi produced in Benin

Shahin A (2007) Removal of aflatoxin B1 from contaminated liquid media by dairy lactic acid bacteria Int J Agri Biol 9:71-75

Shils ME (1994) National Dairy Council Award for Excellence in Medical and Dental Nutrition Education Lecture, 1994: nutrition education in medical schools - the prospect before us. Oxford University Press,

Tajkarimi M, Aliabadi-Sh F, Nejad AS, Poursoltani H, Motallebi A, Mahdavi H (2008a) Aflatoxin M1 contamination in winter and summer milk in 14 states in Iran Food Control 19:1033-1036

van Egmond HP, Dragacci S (2001) Liquid Chromatographic Method for Aflatoxin M 1 in Milk Mycotoxin Protocols:59-69

van Egmond HP, Schothorst RC, Jonker MA (2007) Regulations relating to mycotoxins in food Analytical and bioanalytical chemistry 389:147-157

Yuanling L, Mark E, Baker B, Todd Y, Bonner Denton M (1996) Quantitative Analysis of Aflatoxins by HighPerformance Thin-Layer Chromatography Utilizing a Scientifically Operated Charge-Coupled Device Detector. Analul Chemistry 68: 22 3885-3891

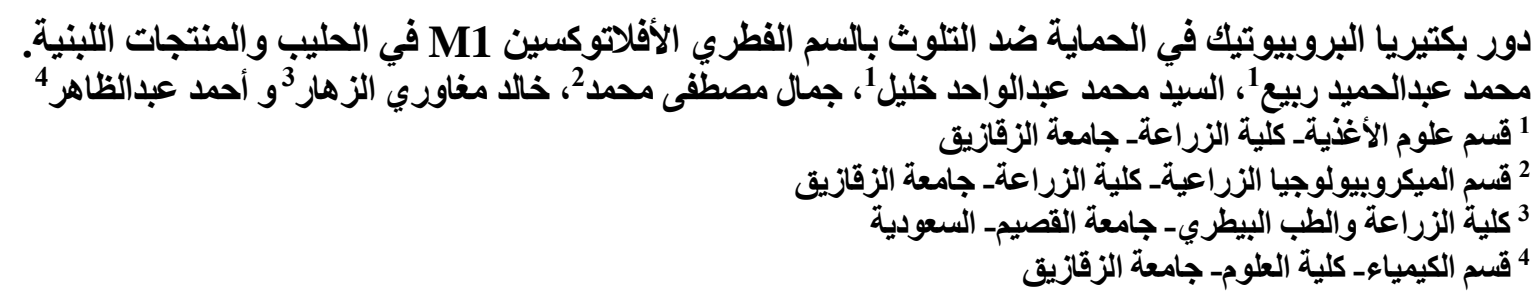

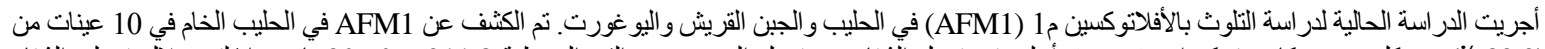

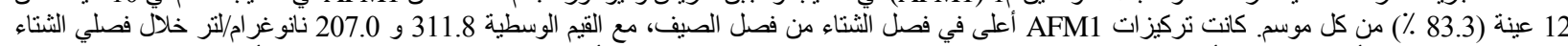

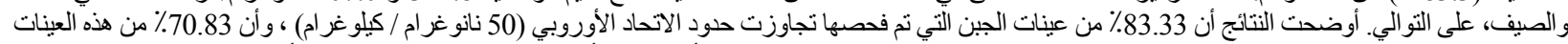

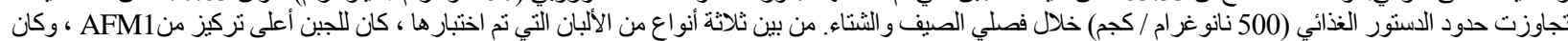

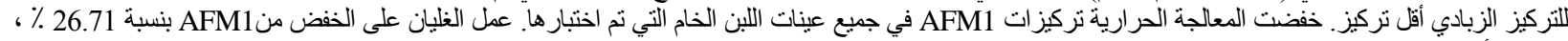

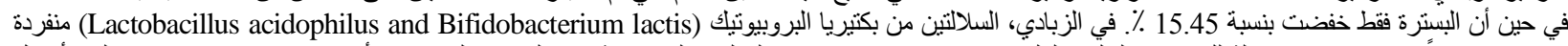
خفضت تدريجياً تركيز

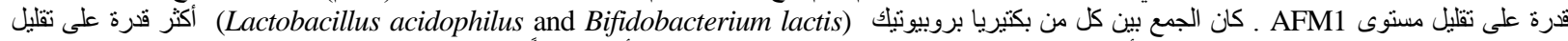

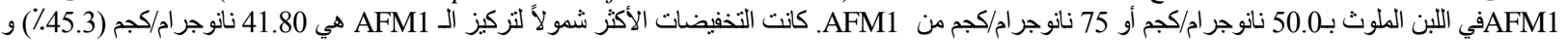

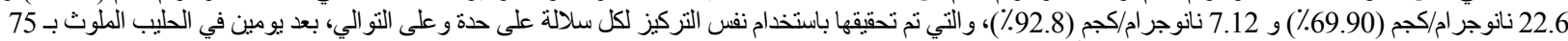
نانوجر ام/كجم. لم ينم ملاحظة وجود 69.6 و AFM1 بعد ثلاثة أيام باستخدام السلالات مجتمعة. 